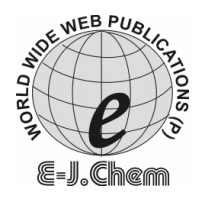

http://www.e-journals.net
ISSN: 0973-4945; CODEN ECJHAO

E-Journal of Chemistry 2010, 7(3), 875-881

\title{
Application of Heteropoly Acids as Heterogeneous and Recyclable Catalysts for Friedländer Synthesis of Quinolines
}

\author{
MAJID M. HERAVI*, NEGAR MOKHTARI HAJ, BITA BAGHERNEJAD, \\ Y. SH. BEHESHTIA and FATEMEH F. BAMOHARRAM ${ }^{\S}$
}

\author{
Department of Chemistry, School of Science, \\ Azzahra University, Vanak, Tehran, Iran. \\ ${ }^{\S}$ Department of Chemistry, School of Sciences, \\ Azad University Khorasan Branch, Mashhad, Iran. \\ mmh1331@yahoo.com
}

Received 18 October 2009; Accepted 15 December 2009

\begin{abstract}
New convenient conditions for the Friedländer synthesis of quinolines are described. Quinolines were readily prepared in the presence of heteropolyacids as heterogeneous and recyclable catalysts in good yields.
\end{abstract}

Keywords: Quinolines, Friedlander annulation, $\alpha$-Methylene group, $o$-Amino acetophenone, Heteropoly acids.

\section{Introduction}

Quinoline is a well-known structural unit in alkaloids, therapeutics and synthetic analogues with interesting biological activities such as antimalarial, antibacterial, antiasthmatic, antihypertensive, anti-inflammatory and tyrokinase PDGF-RTK inhibiting agents ${ }^{1,2}$. They are also applied for the preparation of nano- and mesostructures having enhanced electronic and photonic properties ${ }^{3}$. Thus, the synthesis of quinolines is an important and useful task in organic chemistry. Various methods such as Skraup, Doebner von Miller, Friedländer and Combes methods have been developed for the preparation of quinoline derivatives ${ }^{4,5}$. Among them, Friedländer annulation is one of the most simple and straightforward approaches for the synthesis of polysubstituted quinolines ${ }^{5}$. Friedländer reactions are generally carried out either by refluxing an aqueous or alcoholic solution of reactants in the presence of base or by heating a mixture of the reactants at high temperatures ranging from $150-220^{\circ} \mathrm{C}$ in the absence of catalyst ${ }^{6}$. Under thermal or base catalysis conditions, $o$ - aminobenzophenone 
fails to react with simple ketones such as cyclohexanone, deoxybenzoin and $\beta$-keto esters ${ }^{7}$. Subsequent work showed that acid catalysts are more effective than base catalysts for the Friedländer annulation ${ }^{8}$. Acid catalysts such as hydrochloric acid, sulfuric acid, $p$-toluenesulfonic acid and phosphoric acids are widely used for this conversion ${ }^{7 \mathrm{a}, 9}$. However, many of these classical methods require high temperatures, prolonged reaction times and drastic conditions and the yields reported are far from satisfactory due to the occurrence of several side reactions. Therefore, new catalytic systems are being continuously explored in search of improved efficiencies and cost effectiveness ${ }^{10}$. In recent times, iodine ${ }^{11}$, Lewis acids such as $\mathrm{ZnCl}_{2}$ and $\mathrm{AuCl}_{3} \cdot 3 \mathrm{H}_{2} \mathrm{O},{ }^{12}$ a combination of acidic catalysts [e.g., $\mathrm{NaAuCl}_{4}, \mathrm{Bi}(\mathrm{OTf})_{3}$, $\left.\mathrm{Nd}(\mathrm{NO} 3)_{3} \cdot 6 \mathrm{H}_{2} \mathrm{O}\right]^{13}$ and microwave irradiation ${ }^{14}$ and ionic liquids ${ }^{15}$ have all been found to be effective for this conversion.

Even some of these methods also suffer form harsh reaction conditions, low yields, high temperature, tedious work-up and the use of stoichiometric and relatively expensive reagents. Since quinoline derivatives are increasingly useful and important in drugs and pharmaceuticals, the development of simple, convenient and high yielding protocols is desirable. As a part of our continuing effort towards the development of useful synthetic methodologies ${ }^{16-19}$, here we report our work on the application of heteropolyacids as heterogeneous and recyclable catalysts for Friedländer synthesis of quinolines (Scheme 1).

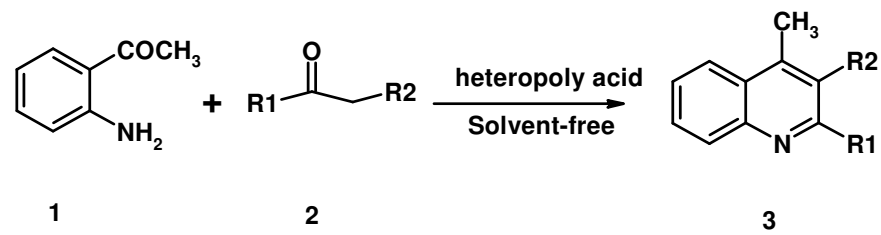

\section{Experimental}

Scheme 1

All the chemicals were obtained from Merck Company and used as received. $\mathrm{H}_{6}\left[\mathrm{PMo}_{9} \mathrm{~V}_{3} \mathrm{O}_{40}\right], \mathrm{H}_{5}\left[\mathrm{PMo}_{10} \mathrm{~V}_{2} \mathrm{O}_{40}\right]$ and $\mathrm{H}_{6}\left[\mathrm{P}_{2} \mathrm{~W}_{18} \mathrm{O}_{62}\right]$ were prepared according to the literature $^{25}$. The integrity of the synthesized heteropolyacids has been proven by comparing of spectral data with those reported in literatur. ${ }^{26-29}$.All products are known compounds and were characterized by $\mathrm{mp}$, IR, ${ }^{1} \mathrm{H}$ NMR and GC/MS. Melting points were measured by using the capillary tube method with an electrothermal 9200 apparatus. ${ }^{1}$ HNMR spectra were recorded on a Bruker AQS AVANCE-500 $\mathrm{MHz}$ spectrometer using TMS as an internal standard $\left(\mathrm{CDCl}_{3}\right.$ solution). IR spectra were recorded from $\mathrm{KBr}$ disk on the FT-IR Bruker Tensor 27. GC/MS spectra were recorded on an Agilent Technologies 6890 network GC system and an Agilent 5973 network Mass selective detector. Thin layer chromatography (TLC) on commercial aluminumbacked plates of silica gel, 60 F254 was used to monitor the progress of reactions. All products were characterized by spectra and physical data.

\section{Typical procedure for preparation of 2,4-dimetyl quinoline-3-carboxylate (3a)}

A mixture of 2-amino acetophenone $(1 \mathrm{mmol})$, ethyl acetoacetate $(1.2 \mathrm{mmol})$ and $\mathrm{H}_{6}\left[\mathrm{P}_{2} \mathrm{~W}_{18} \mathrm{O}_{62}\right]\left(9 \times 10^{-3} \mathrm{mmol}\right)$ was stirred at $70^{\circ} \mathrm{C}$ under solvent-free conditions for the appropriate time (Table 1). After completion of the reaction, as indicated by TLC, the reaction mixture was extracted with diethyl ether $(3 \times 10 \mathrm{~mL})$. The combined organic layers were dried over anhydrous $\mathrm{MgSO}_{4}$ and the solvent was evaporated to afford pure quinolines. 
Table 1. $\mathrm{H}_{6}\left[\mathrm{P}_{2} \mathrm{~W}_{18} \mathrm{O}_{62}\right]$ catalyzed synthesis of Friedländer Quionlines.

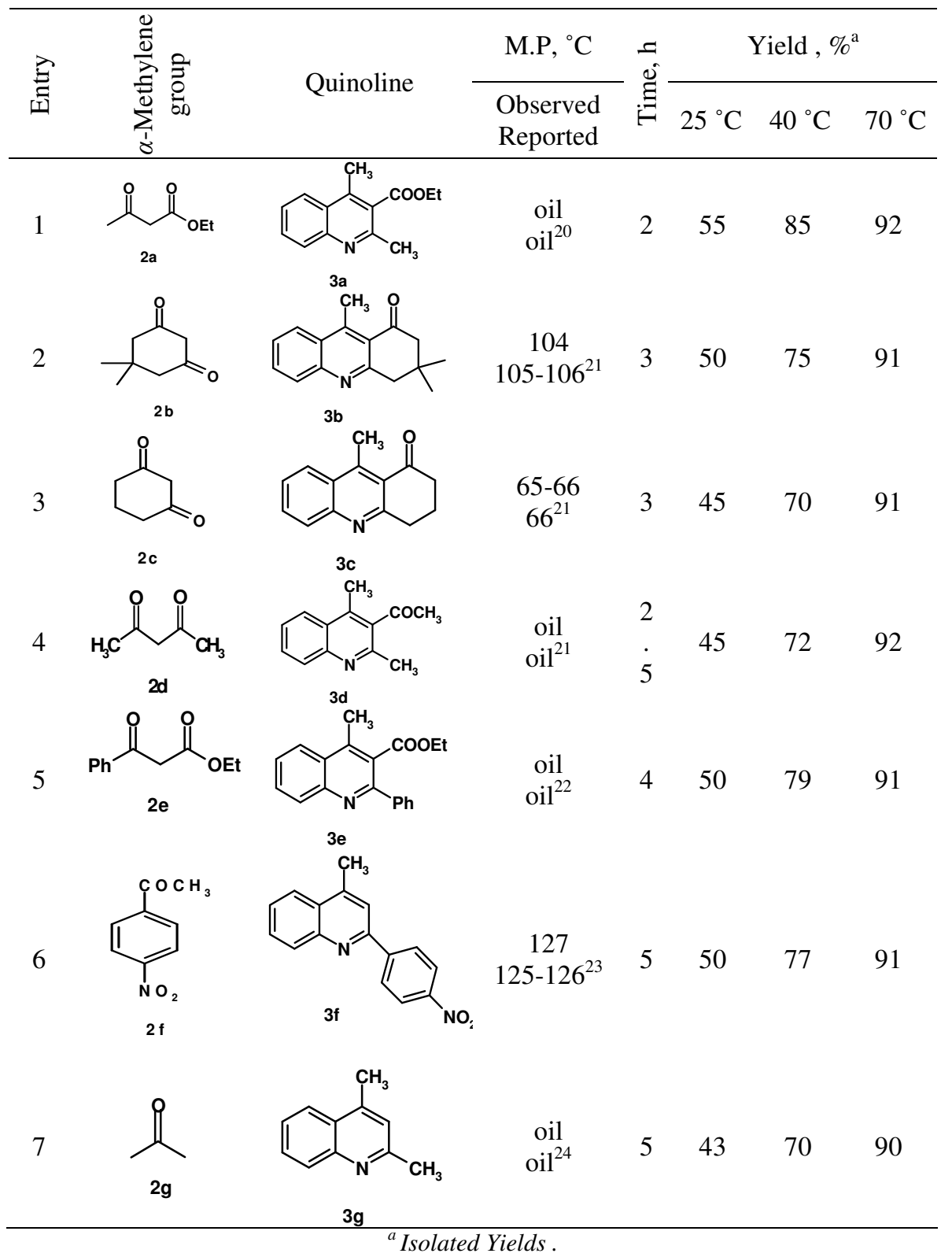

3a : ${ }^{1} \mathrm{H}$ NMR $\left(\mathrm{CDCl}_{3}, 500 \mathrm{MHz}\right): \delta 7.99(\mathrm{~d}, J=7.3 \mathrm{~Hz}, 1 \mathrm{H}), 7.97(\mathrm{~d}, J=7.3 \mathrm{~Hz}, 1 \mathrm{H})$, $7.69(\mathrm{t}, J=7.3 \mathrm{~Hz}, 1 \mathrm{H}), 7.51(\mathrm{t}, J=7.3 \mathrm{~Hz}, 1 \mathrm{H}), 4.46(\mathrm{q}, J=7.1 \mathrm{~Hz}, 2 \mathrm{H}), 2.70(\mathrm{~s}, 3 \mathrm{H}), 2.62$ (s, 3H), 1.46 (t, $J=7.1 \mathrm{~Hz}, 3 \mathrm{H})$; GC/Ms: $230(\mathrm{M}++1)$.

3b: ${ }^{1} \mathrm{H} \mathrm{NMR}\left(\mathrm{CDCl}_{3}, 500 \mathrm{MHz}\right): 8.47(\mathrm{~d}, J=8.4 \mathrm{~Hz}, 1 \mathrm{H}), 8.59(\mathrm{~d}, J=8.4 \mathrm{~Hz}, 1 \mathrm{H})$, $\delta=8.07(\mathrm{t}, J=8.4 \mathrm{~Hz}, 1 \mathrm{H}), 8.05(\mathrm{t}, J=8.4 \mathrm{~Hz}, 1 \mathrm{H}), 3.24(\mathrm{~s}, 2 \mathrm{H}), 3.06(\mathrm{~s}, 3 \mathrm{H}), 2.54$ (s, 2H), 1.16 (s, 6H) ; GC/Ms: 239 (M++1). 


\section{Reusability of the catalyst}

We investigated the reusability and recycling of heteropoly acids. At the end of the reaction, the catalyst could be recovered by a simple filtration. The recycled catalyst could be washed with methanol and subjected to a second run of the reaction process. To assure that catalysts were not dissolved in methanol, the catalysts were weighed after filtration and before using and reusing for the next reaction. The results show that these catalysts are not soluble in methanol. In Table 4, the comparison of efficiency of $\mathrm{H}_{6}\left[\mathrm{P}_{2} \mathrm{~W}_{18} \mathrm{O}_{62}\right]$ in synthesis of $\mathbf{3 a}$ after five times is reported. As it is shown in Table 4 the first and second reaction using recovered $\mathrm{H}_{6}\left[\mathrm{P}_{2} \mathrm{~W}_{18} \mathrm{O}_{62}\right]$ afforded similar yield to those obtained in the first run. In the third, fourth and fifth runs, the yields were gradually decreased.

\section{Results and Discussion}

In a typical example we have carried out a reaction of 2-amino acetophenone with ethyl acetoacetate in the presence of Wells-Dawson type of heteropoly acid $\mathrm{H}_{6}\left[\mathrm{P}_{2} \mathrm{~W}_{18} \mathrm{O}_{62}\right]$ under solvent-free condition to afford the corresponding ethyl 2,4-dimetyl quinoline-3-carboxylate (3a) in $92 \%$ yield without any side products. These two components coupling reaction proceeded efficiently under solvent-free condition with high selectivity. Both ketones and $\beta$ keto esters afforded excellent yields of products in a short reaction time. In the absence of catalyst, the reaction did not yield any product even after long reaction time (8-12 h). This method not only affords the products in good yields but also avoids the problems associated with catalyst cost, handling, safety and pollution. These catalysts can act as eco-friendly for a variety of organic transformations, non-volatile, non-explosive, easy to handle and thermally robust. This method is equally effective for both cyclic and acyclic ketones. The scope and generality of this process is illustrated by reacting various ketones and $\beta$-keto esters. The results are presented in Table 1. In all cases, the reactions proceeded rapidly under solvent-free condition with high efficiency.

\section{Effect of the catalyst type}

Initially, we compared the catalytic performance of Keggin, $\mathrm{H}_{5}\left[\mathrm{PMo}_{10} \mathrm{~V}_{2} \mathrm{O}_{40}\right]$, $\mathrm{H}_{6}\left[\mathrm{PMo}_{9} \mathrm{~V}_{3} \mathrm{O}_{40}\right]$ with Wells-Dawson, $\mathrm{H}_{6}\left[\mathrm{P}_{2} \mathrm{~W}_{18} \mathrm{O}_{62}\right]$ in the synthesis of quinoline derivatives. The results are shown in Table 2 . The yield of product decreases in the following order:

$$
\mathrm{H}_{6}\left[\mathrm{P}_{2} \mathrm{~W}_{18} \mathrm{O}_{62}\right]>\mathrm{H}_{5}\left[\mathrm{PMo}_{10} \mathrm{~V}_{2} \mathrm{O}_{40}\right]>\mathrm{H}_{6}\left[\mathrm{PMo}_{9} \mathrm{~V}_{3} \mathrm{O}_{40}\right]
$$

As could be seen Wells-Dawson type of heteropoly acid $\mathrm{H}_{6}\left[\mathrm{P}_{2} \mathrm{~W}_{18} \mathrm{O}_{62}\right]$, is more effective than the other heteropoly anions and in the presence of this catalyst the highest yields of products are obtained. The interesting feature of this poly anion compared the other heteropoly acids is its hydrolytic stability $(\mathrm{pH} 0-12)$, which is very important in catalytic processes. In addition this poly anion is more stable than the Keggin catalysts under thermal conditions, which makes high temperature for the reactions possible.

A significant interpretation for observed different activities of tested heteropoly anions is very difficult. Their properties can be varied by their constitutive elements as heteroatom, polyatom, and counter-cation. However, because one of the important factors that affect the oxidation capacity and activity of poly anions which is the energy gap between the highest occupied molecular orbital (HOMO) and the lowest unoccupied orbital (LUMO), it is suggested that the energy and composition of the LUMOs have significant effects on the redox properties and activity of the studied poly anions as catalyst. The highest activity for 
$\mathrm{H}_{6}\left[\mathrm{P}_{2} \mathrm{~W}_{18} \mathrm{O}_{62}\right]$ is attributed to the energy and composition of the LUMO, strong acidic property, and higher acidic protons. The larger number of protons may low the activation barrier and the large anion can provide many sites on the oval-shaped molecule that are likely to render the catalyst effective.

Table 2. Synthesis of Quionlines using various heteropoly acids under solvent-free condition.

\begin{tabular}{|c|c|c|c|}
\hline Entry & Catalyst & Product & Yield, $\%^{\mathrm{a}}$ \\
\hline \multirow[t]{3}{*}{1} & $\mathrm{H}_{6}\left[\mathrm{P}_{2} \mathrm{~W}_{18} \mathrm{O}_{62}\right]$ & $3 \mathbf{a}$ & 92 \\
\hline & $\mathrm{H}_{5}\left[\mathrm{PMo}_{10} \mathrm{~V}_{2} \mathrm{O}_{40}\right]$ & $3 \mathbf{a}$ & 88 \\
\hline & $\mathrm{H}_{6}\left[\mathrm{PMo}_{9} \mathrm{~V}_{3} \mathrm{O}_{40}\right]$ & $3 \mathbf{a}$ & 85 \\
\hline \multirow[t]{3}{*}{2} & $\mathrm{H}_{6}\left[\mathrm{P}_{2} \mathrm{~W}_{18} \mathrm{O}_{62}\right]$ & $3 \mathbf{b}$ & 91 \\
\hline & $\mathrm{H}_{5}\left[\mathrm{PMo}_{10} \mathrm{~V}_{2} \mathrm{O}_{40}\right]$ & $3 \mathbf{b}$ & 85 \\
\hline & $\mathrm{H}_{6}\left[\mathrm{PMo}_{9} \mathrm{~V}_{3} \mathrm{O}_{40}\right]$ & $3 \mathbf{b}$ & 80 \\
\hline \multirow[t]{3}{*}{3} & $\mathrm{H}_{6}\left[\mathrm{P}_{2} \mathrm{~W}_{18} \mathrm{O}_{62}\right]$ & $3 c$ & 91 \\
\hline & $\mathrm{H}_{5}\left[\mathrm{PMo}_{10} \mathrm{~V}_{2} \mathrm{O}_{40}\right]$ & $3 c$ & 86 \\
\hline & $\mathrm{H}_{6}\left[\mathrm{PMo}_{9} \mathrm{~V}_{3} \mathrm{O}_{40}\right]$ & $3 c$ & 83 \\
\hline \multirow[t]{3}{*}{4} & $\mathrm{H}_{6}\left[\mathrm{P}_{2} \mathrm{~W}_{18} \mathrm{O}_{62}\right]$ & 3d & 92 \\
\hline & $\mathrm{H}_{5}\left[\mathrm{PMo}_{10} \mathrm{~V}_{2} \mathrm{O}_{40}\right]$ & 3d & 85 \\
\hline & $\mathrm{H}_{6}\left[\mathrm{PMo}_{9} \mathrm{~V}_{3} \mathrm{O}_{40}\right]$ & 3d & 81 \\
\hline \multirow[t]{3}{*}{5} & $\mathrm{H}_{6}\left[\mathrm{P}_{2} \mathrm{~W}_{18} \mathrm{O}_{62}\right]$ & $3 \mathbf{e}$ & 91 \\
\hline & $\mathrm{H}_{5}\left[\mathrm{PMo}_{10} \mathrm{~V}_{2} \mathrm{O}_{40}\right]$ & $3 \mathbf{e}$ & 83 \\
\hline & $\mathrm{H}_{6}\left[\mathrm{PMo}_{9} \mathrm{~V}_{3} \mathrm{O}_{40}\right]$ & $3 \mathbf{e}$ & 79 \\
\hline \multirow[t]{3}{*}{6} & $\mathrm{H}_{6}\left[\mathrm{P}_{2} \mathrm{~W}_{18} \mathrm{O}_{62}\right]$ & $3 f$ & 91 \\
\hline & $\mathrm{H}_{5}\left[\mathrm{PMo}_{10} \mathrm{~V}_{2} \mathrm{O}_{40}\right]$ & 3f & 85 \\
\hline & $\mathrm{H}_{6}\left[\mathrm{PMo}_{9} \mathrm{~V}_{3} \mathrm{O}_{40}\right]$ & 3f & 80 \\
\hline \multirow[t]{3}{*}{7} & $\mathrm{H}_{6}\left[\mathrm{P}_{2} \mathrm{~W}_{18} \mathrm{O}_{62}\right]$ & $3 g$ & 90 \\
\hline & $\mathrm{H}_{5}\left[\mathrm{PMo}_{10} \mathrm{~V}_{2} \mathrm{O}_{40}\right]$ & $3 g$ & 84 \\
\hline & $\mathrm{H}_{6}\left[\mathrm{PMo}_{9} \mathrm{~V}_{3} \mathrm{O}_{40}\right]$ & $3 g$ & 80 \\
\hline
\end{tabular}

The reaction was studied with various moles of $\mathrm{H}_{6}\left[\mathrm{P}_{2} \mathrm{~W}_{18} \mathrm{O}_{62}\right]$ from $2 \times 10^{-3}$ mmol to $9 \times 10^{-3}$ mmol. In all cases, with $9 \times 10^{-3} \mathrm{mmol}$ catalyst, the maximum yields of quinoline derivatives was obtained within 2-3 h. The progress of the reaction was followed by TLC and GC and the results indicate that the yields were affected by changing the catalyst moles. The reactions proceeded well with $9 \times 10^{-3} \mathrm{mmol}$ catalyst and use of an increased amount of catalyst does not make much difference.

\section{Effect of temperature}

The effect of temperature was studied by carrying out the reactions at different temperatures $\left[25^{\circ} \mathrm{C}, 50{ }^{\circ} \mathrm{C}\right.$ and $\left.\left.70^{\circ} \mathrm{C}\right)\right]$. As it shown in Tables 1 by raising the reaction temperature from ambient temperature $\left(25^{\circ} \mathrm{C}\right)$ to $70{ }^{\circ} \mathrm{C}$, the yield of reactions increased. From these results, it was decided that $70{ }^{\circ} \mathrm{C}$ would be the best temperature for all reactions. The reaction proceeds very cleanly under solvent-free condition and free of side products.

\section{Effect of the solvent}

The synthesis of quinoline derivatives at reflux temperature was carried out using various common solvents such as acetic acid, ethanol, methanol, THF and acetonitrile. The results are shown in Table 4. With using all of the catalysts the highest yield of products was obtained under solvent-free condition. In addition, the time required for completion of the reaction was found to be less under solvent-free condition. 
Table 3. Synthesis of $\mathbf{3 a}$ in the presence of different solvents.

\begin{tabular}{|c|c|c|c|c|c|}
\hline Entry & Solvent & Catalyst & $\begin{array}{c}\text { Temperature, } \\
{ }^{\circ} \mathrm{C}\end{array}$ & Time, $\mathrm{h}$ & Yield, $\%^{\mathrm{a}}$ \\
\hline \multirow[t]{3}{*}{1} & - & $\mathrm{H}_{6}\left[\mathrm{P}_{2} \mathrm{~W}_{18} \mathrm{O}_{62}\right]$ & $70^{\circ} \mathrm{C}$ & 2 & 92 \\
\hline & - & $\mathrm{H}_{5}\left[\mathrm{PMo}_{10} \mathrm{~V}_{2} \mathrm{O}_{40}\right]$ & $70^{\circ} \mathrm{C}$ & 2.5 & 88 \\
\hline & - & $\mathrm{H}_{6}\left[\mathrm{PMo}_{9} \mathrm{~V}_{3} \mathrm{O}_{40}\right]$ & $70^{\circ} \mathrm{C}$ & 2.5 & 85 \\
\hline \multirow[t]{3}{*}{2} & Acetic acid & $\mathrm{H}_{6}\left[\mathrm{P}_{2} \mathrm{~W}_{18} \mathrm{O}_{62}\right]$ & Reflux & 3 & 89 \\
\hline & Acetic acid & $\mathrm{H}_{5}\left[\mathrm{PMo}_{10} \mathrm{~V}_{2} \mathrm{O}_{40}\right]$ & Reflux & 3.5 & 84 \\
\hline & Acetic acid & $\mathrm{H}_{6}\left[\mathrm{PMo}_{9} \mathrm{~V}_{3} \mathrm{O}_{40}\right]$ & Reflux & 3.5 & 80 \\
\hline \multirow[t]{3}{*}{3} & acetonitrile & $\mathrm{H}_{6}\left[\mathrm{P}_{2} \mathrm{~W}_{18} \mathrm{O}_{62}\right]$ & Reflux & 4 & 84 \\
\hline & acetonitrile & $\mathrm{H}_{5}\left[\mathrm{PMo}_{10} \mathrm{~V}_{2} \mathrm{O}_{40}\right]$ & Reflux & 5 & 80 \\
\hline & acetonitrile & $\mathrm{H}_{6}\left[\mathrm{PMo}_{9} \mathrm{~V}_{3} \mathrm{O}_{40}\right]$ & Reflux & 5 & 80 \\
\hline \multirow[t]{3}{*}{4} & Ethanol & $\mathrm{H}_{6}\left[\mathrm{P}_{2} \mathrm{~W}_{18} \mathrm{O}_{62}\right]$ & Reflux & 4 & 77 \\
\hline & Ethanol & $\mathrm{H}_{5}\left[\mathrm{PMo}_{10} \mathrm{~V}_{2} \mathrm{O}_{40}\right]$ & Reflux & 5 & 75 \\
\hline & Ethanol & $\mathrm{H}_{6}\left[\mathrm{PMo}_{9} \mathrm{~V}_{3} \mathrm{O}_{40}\right]$ & Reflux & 5 & 70 \\
\hline \multirow[t]{3}{*}{5} & THF & $\mathrm{H}_{6}\left[\mathrm{P}_{2} \mathrm{~W}_{18} \mathrm{O}_{62}\right]$ & Reflux & 4 & 75 \\
\hline & THF & $\mathrm{H}_{5}\left[\mathrm{PMo}_{10} \mathrm{~V}_{2} \mathrm{O}_{40}\right]$ & Reflux & 5 & 70 \\
\hline & THF & $\mathrm{H}_{6}\left[\mathrm{PMo}_{9} \mathrm{~V}_{3} \mathrm{O}_{40}\right]$ & Reflux & 5 & 70 \\
\hline \multirow[t]{3}{*}{6} & methanol & $\mathrm{H}_{6}\left[\mathrm{P}_{2} \mathrm{~W}_{18} \mathrm{O}_{62}\right]$ & Reflux & 4 & 75 \\
\hline & methanol & $\mathrm{H}_{5}\left[\mathrm{PMo}_{10} \mathrm{~V}_{2} \mathrm{O}_{40}\right]$ & Reflux & 5 & 70 \\
\hline & methanol & $\mathrm{H}_{6}\left[\mathrm{PMo}_{9} \mathrm{~V}_{3} \mathrm{O}_{40}\right]$ & Reflux & 5 & 70 \\
\hline \multirow[t]{3}{*}{7} & $\mathrm{CHCl}_{3}$ & $\mathrm{H}_{6}\left[\mathrm{P}_{2} \mathrm{~W}_{18} \mathrm{O}_{62}\right]$ & Reflux & 5 & 75 \\
\hline & $\mathrm{CHCl}_{3}$ & $\mathrm{H}_{5}\left[\mathrm{PMo}_{10} \mathrm{~V}_{2} \mathrm{O}_{40}\right]$ & Reflux & 6 & 73 \\
\hline & $\mathrm{CHCl}_{3}$ & $\mathrm{H}_{6}\left[\mathrm{PMo}_{9} \mathrm{~V}_{3} \mathrm{O}_{40}\right]$ & Reflux & 6 & 70 \\
\hline
\end{tabular}

\section{${ }^{a}$ Isolated Yields .}

Table 4. Reuse of the $\mathrm{H}_{6}\left[\mathrm{P}_{2} \mathrm{~W}_{18} \mathrm{O}_{62}\right]$ for synthesis of $\mathbf{3 a}$.

\section{References}

\begin{tabular}{ccc}
\hline Yield, $\%^{\mathrm{a}}$ & Time, $\mathrm{h}$ & Entry \\
\hline 92 & 2 & 1 \\
90 & 2.5 & 2 \\
84 & 3 & 3 \\
80 & 3 & 4 \\
75 & 3.5 & 5 \\
\hline \multicolumn{3}{c}{ a Isolated Yields. }
\end{tabular}

1. Larsen R D, Corley E G, King A O, Carrol J D, Davis P, Verhoeven T R, Reider P J, Labelle M, Gauthier J Y, Xiang Y B and Zamboni R J, J Org Chem., 1996, 61, 3398;

2. (a) Roma G, Braccio M D, Grossi G, Mattioli F and Ghia M, Eur J Med Chem., 2000, 35, 1021; (b) Michael J P, Nat Prod Rep., 1997, 14, 605; (c) Chen Y L, Fang K C, Sheu J Y, Hsu S L and Tzeng C C, J Med Chem., 2001, 44, 2374.

3. (a) Kalluraya B and Sreenivasa S, Farmaco., 1998, 53, 399; (b) Doube D, Blouin M, Brideau C, Chan C, Desmarais S, Either D, Falgueyret J P, Friesen R W, Girard M, Girard Y, Guay J, Tagari P and Young R N, Bioorg Med Chem Lett., 1998, 8, 1255; (c) Maguire M P, Sheets K R, McVety K, Spada A P and Zilberstein A, J Med Chem., 1994, 37, 2129.

4. Zhang X, Shetty A S and Jenekhe S A, Macromolecules, 1999, 32, 7422. 
5. (a) Jones G, In Comprehensive Heterocyclic Chemistry II, Katritzky A R and Rees C W, Eds; Pergamon Press: New York, 1996, 5, 167; (b) Cho C S, Oh B H, Kim T J and Shim S C, Chem Commun., 2000, 1885 and references therein; (c) Jiang B and Si Y C, J Org Chem., 2002, 67, 9449.

6. (a) Skraup H, Chem Ber., 1880, 13, 2086; (b) Friedländer P, Ber., 1882, 15, 2572; (c) Mansake R H F and Kulka M, Org React., 1953, 7, 59; (d) Linderman R J and Kirollos S K, Tetrahedron Lett., 1990, 31, 2689; (e) Theoclitou M E, Robinson L A, Tetrahedron Lett., 2002, 43, 3907.

7. (a) Cheng C C and Yan S J, Org React., 1982, 28, 37; (b) Thummel R P, Synlett., 1992, 1; (c) Eckert H, Angew Chem Int Ed Engl., 1981, 20, 208; (d) Gladiali S, Chelucci G, Mudadu M S, Gastaut M A and Thummel R P, J Org Chem., 2001, 66, 400.

8. Fehnel E A, J Heterocycl Chem., 1966, 31, 2899.

9. (a) Strekowski L and Czamy A, J Fluor Chem., 2000, 104, 281; (b) Hu Y Z, Zang G and Thummel R P, Org Lett., 2003, 5, 2251.

10. (a) Kwon T W, Song S J and Cho S J, Tetrahedron Lett., 2003, 44, 255; (b) Yadav J S, Reddy B V S, Rao R S, Kumar V N and Nagaiah K, Synthesis, 2003, 1610; (c) Cho S C, Oh B O and Shin S C, Tetrahedron Lett., 1999, 40, 1499.

11. Wu J, Xia H G and Gao K, Org Biomol Chem., 2006, 4, 126.

12. (a) Arcadi A, Chiarini M, Di Giuseppe S and Marinelli F, Synlett., 2003, 203;

(b) McNaughton B R and Miller B L, Org Lett., 2003, 5, 4257; (c) Walser A, Flyll T, Fryer R I, J Heterocycl Chem., 1975, 12, 737.

13. (a) Arcadi A, Chiarini M, Di Guespe S and Marinelly F, Synlett., 2003, 203; (b) Yadav J S, Reddy B V S and Premalatha K, Synlett., 2004, 963; (c) Varala R, Enugala R and Adapa S R, Synthesis, 2006, 3825.

14. (a) Song S J, Cho S J, Park D K, Kwon T W and Jenekhe S A, Tetrahedron Lett., 2003, 44, 255; (b) Jia C S, Zhang Z, Tu S J and Wang G W, Org Biomol Chem., 2006, 4, 104.

15. (a) Wang J, Fan X, Zhang X and Han Can L, Can J Chem., 2004, 82, 1192; (b) Palimkar S S, Siddiqui S A, Daniel T, Lahoti R J and Srinivasan J V, J Org Chem., 2003, 68, 9371;

(c) Karthikeyan G and Perumal P T, J Heterocyclic Chem., 2004, 41, 1039.

16. Heravi M M, Oskooie H A and Baghernejad B, J Chin Chem Soc., 2007, 54, 767.

17. Heravi M M, Hekmatshoar R and Pedram L, J Mol Catal A: Chem., 2005, 89, 231.

18. Bamoharram F F, Heravi M M and Roshani M, J Chin Chem Soc., 2007, 54, 1017.

19. Heravi M M, Bakhtiari K and Bamoharram F F, Catal Commun.,. 2006, 7, 373.

20. Yadav J S, Reddy B V S, Sreedar P, Srinivasa, Rao R and Nagaiah K, Synthesis, 2004, 2381.

21. Wang G W, Jia C S and Dong Y W, Tetrahedron Lett., 2006, 47, 1053.

22. Varala R, Enugala R R and Adapa S R, Synthesis, 2006, 3825.

23. Qiang L G and Baine N H, J Org Chem., 1988, 53, 4218.

24. Bowman,a, W R, Fletcher A J, Pedersen J M, Lovell P J, Elsegood M R J, Lopez E H, McKeea V and Pottsa G B S, Tetrahedron,.2007, 63, 191.

25. Kozhevnikov I.V, Catalysts for fine chemical synthesis Catalysis by polyoxometalates, Wiley, England, 2002, 2.

26. Alizadeh M H, Harmalker S P, Jeanenin Y, Martin- Frere J and Pope M T, J Am Chem Soc., 1985, 107, 2662.

27. Tsigdinos G A and Hallada C J, Inorg Chem., 1968, 7, 437.

28. Pope M T, Heteropoly and Isopoly Oxometalates, Springer, Berlin, 1983.

29. Baronetti G T, Briand L, Sedran U and Thomas H, Appl Catal A: Gen., 1998, 172, 265. 


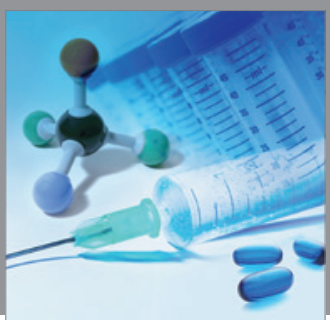

International Journal of

Medicinal Chemistry

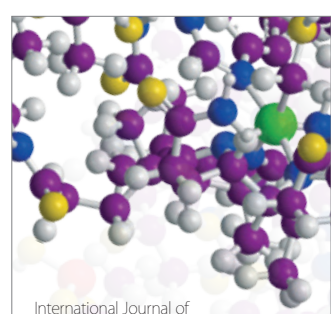

Carbohydrate Chemistry

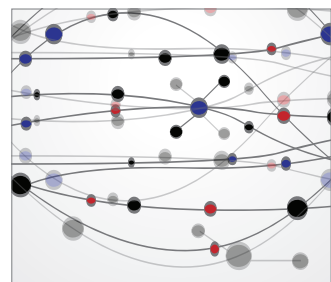

The Scientific World Journal
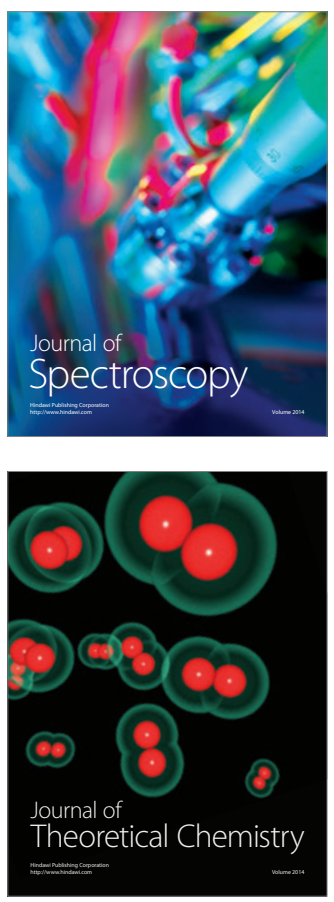
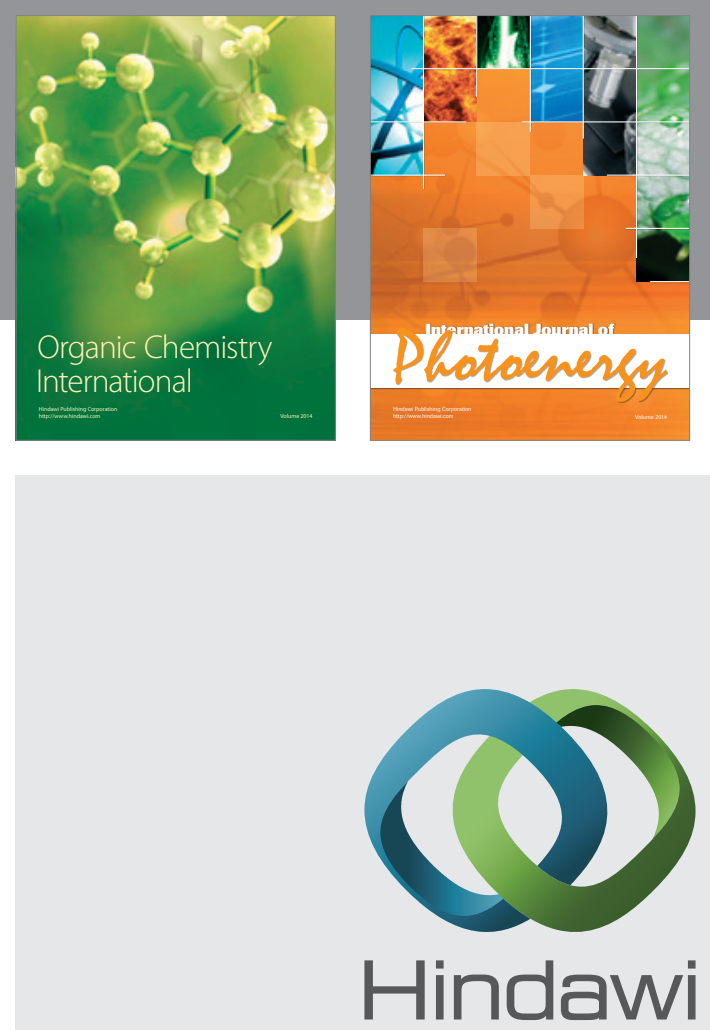

Submit your manuscripts at

http://www.hindawi.com
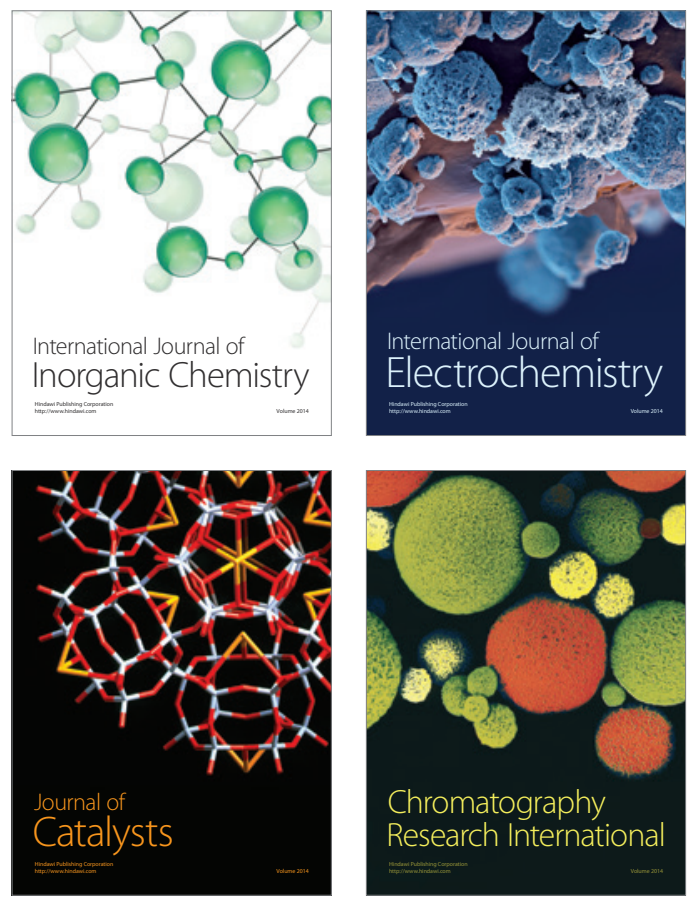
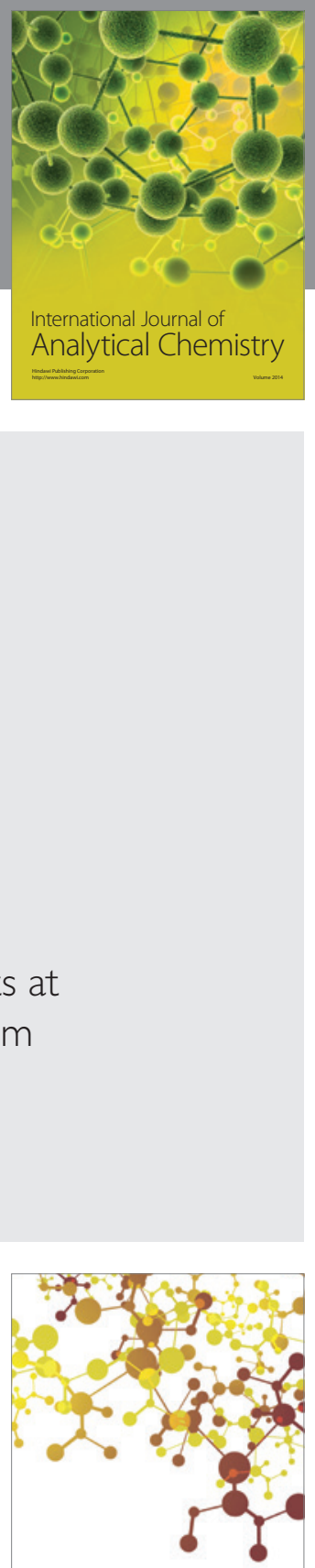

Journal of

Applied Chemistry
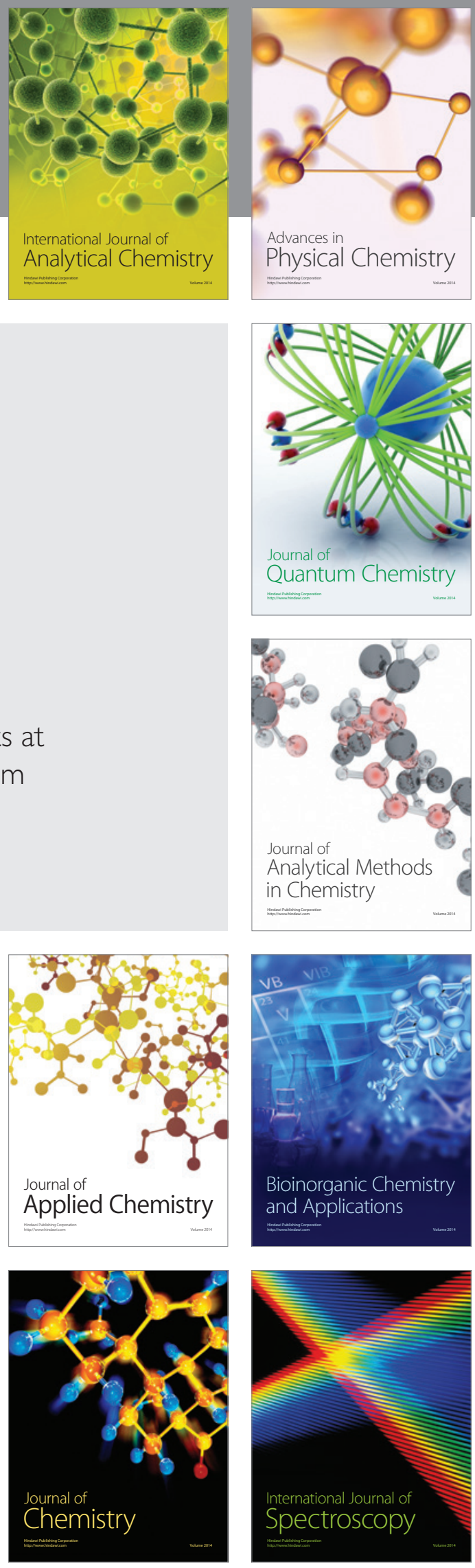